\title{
Determination of microbiological quality of packed and unpacked bread
}

\author{
Afsana Khanom, Tahmina Shammi and Md. Shahidul Kabir* \\ Department of Microbiology, Stamford University Bangladesh, 51 Siddeswari Road, Dhaka 1217, Bangladesh
}

Received 28 May 2016/Accepted 24 June 2016

\begin{abstract}
Wheat and flour contain essential nutrients such as carbohydrate, minerals, fats and proteins which may aid proliferation of microorganisms in products made from cereal grains and kept under improper storage condition. This study was conducted to determine the microbial load of bread and flour sold in packed and unpacked forms by the local and super markets in Dhaka city. Socioeconomic background, awareness of the microbiological contamination, spoilage of bread and flour and hygiene status of the salespeople were also studied to determine any correlation between the contamination of bread and flour sold by local and super markets. About 20 samples of flour $(n=10)$ and bread $(n=10)$ were included in this study to determine the load of total heterotrophic bacteria (THB), total Staphylococcus aureus (TSA), total Enterobacteriaceae (TE), total coliforms (TC), total yeast and mold (TYM). Equal number of unpacked (local market) and packed (supermarket) bread and flour samples were included in this study. TC, TSA and THB counts were found to be $\sim 1.0 \log _{10} \mathrm{cfu} / \mathrm{g}$ higher in unpacked (local market) flour samples compared to those of packed (supermarket) samples. TSA counts were significantly higher in unpacked (local market) samples compared to the packed samples $(p<0.05)$. Food handlers of both the groups did not have adequate knowledge and training on food contamination and spoilage. However, salespeople in the supermarkets were found to be more educated, experienced than those in the local markets. This study demonstrates that unpacked (local market) bread and flour are more contaminated than the packed (supermarket) samples and may pose risk of foodborne infection to consumers.
\end{abstract}

Key words: Flour; Bread; Coliform; Enerobacteriaceae; Contamination

Cereals and cereal products constitute large portion of food resources and consumed by a large number of people worldwide. Bakery products and cereals provide adequate nutrients and calories required every day. Cereals have been consumed as basic food since prehistoric times and long before bread making was developed. Bakery products provide the supply of different essential nutrients such as carbohydrates, proteins, lipids, vitamins and minerals (1). Sales of a variety of breads and other bakery products have been increased in the past decades. Flours are made by grinding grains to that of powdery consistency before they are added to bread preparation. Flours are also found to provide primary structure to the final baked bread. Different types of flours are found worldwide which are made from wheat, rye, barley, maize and other types of grains. Wheat flour and bread constitute a large part of daily diet in rural and urban population. Flours contain higher proportion of carbohydrate (starch) and to lower proportion of minerals, fats and proteins (2). In several countries in the world, up to $50 \%$ of the total required calories are supplied by bread alone $(3,4)$.

Flour and breads are generally regarded as safe food

${ }^{*}$ Corresponding Author: Dr. Md. Shahidul Kabir, Department of Microbiology, and Director, Institutional Quality Assurance Cell (IQAC), Stamford University Bangladesh, 51 Siddeswari Road, Dhaka-1217, Bangladesh. E-mail: kabir@stamforduniversity.edu.bd from the microbiological point of view as they contain low water activity (5). Although growth of pathogenic bacteria may not be supported under such low water activity they may survive for extended periods of time (6). Cereal grains and bakery products held under improper storage conditions may aid in proliferation of various micro-organisms (7). Food poisoning resulting from contaminated flours has been reported in other countries of the world such as, Australian, European and the USA. Pathogenic microorganisms like Salmonella spp., Escherichia coli, Bacillus cereus and other spoilage micro-organisms were found to be present at low levels in wheat and flour (8-12). In addition to the growth of bacteria, growth of mold in flour is known to significantly deteriorate quality of bread and flour. However, there are only a few studies reported on microbiological status of bread and flour in Bangladesh. Therefore, this study was conducted to determine the bioburden in bread and flours sold in packed (super markets) and unpacked (local market) in Dhaka city. Background information of sales people was also investigated to determine any correlation between their level of knowledge and hygiene practice with the loads of different groups of bacteria in studied samples.

\section{MATERIALS AND METHODS}

Collection of sample. A total of 20 fresh samples of bread and flour were 
collected from different local and supermarkets in Dhaka city. Each sample was collected in a sterile sealed polythene bag, appropriately labeled and immediately brought to the microbiology laboratory of Stamford University Bangladesh and stored in the refrigerator $\left(4-8{ }^{\circ} \mathrm{C}\right)$ before processing.

Sample processing. Each sample $(10.0 \mathrm{~g})$ was homogenized with $90.0 \mathrm{ml}$ of sterile normal saline to prepare stock solution. Stocks were serially diluted (1:10) to $10^{-5}$ by adding $100 \mu \mathrm{l}$ of stock solution to $900 \mu \mathrm{l}$ normal saline in eppendorfs tubes. $100 \mu \mathrm{l}$ of diluted sample was inoculated on Nutrient agar (NA), Mannitol Salt Agar (MSA), membrane Faecal Coliform (mFC), Violet Red Bile Salt Glucose agar (VRBG) and Sabouraud Dextrose agar (SDA) media following spread plate method and incubated at $37{ }^{\circ} \mathrm{C}$ for $18-24$ hours except for SDA which was incubated at $25^{\circ} \mathrm{C}$ for $48-72$ hours. All media were procured from Himedia Laboratories Ltd., India.

Determination of total bacterial count. Nutrient agar media was used to determinate the total bacterial count. NA plates were dried and labeled for appropriate dilutions to be used for dilution and spread plate method. Plates were inoculated and incubated at $37{ }^{\circ} \mathrm{C}$ for $18-24$ hours. Total number of bacteria cfu/g of sample was calculated and recorded for interpretation of the result.

Determination of counts of Staphylococcus aureus. MSA was used to determine the counts of Staphylococcus aureus in bread and flour samples. The suspected colonies of $S$. aureus showed yellow color for mannitol fermentation and yellow halo for coagulase production around the colony. Suspected colonies were further confirmed by catalase, coagulase tests and Gram staining technique (13). Typical $S$. aureus colonies were counted to calculate cfu per gram of sample.

Determination of total Enterobacteriaceae. VRBG agar was used for propagation of Enterobacteriaceae. After incubation at $37{ }^{\circ} \mathrm{C}$ for 24 hours characteristic purple and red colonies were counted as members of Enterobacteriaceae. Suspected colonies were counted to determine cfu per gram of sample (14).

Determination of coliform bacteria. Membrane Faecal Coliform (mFC) media was used to detect the coliform bacteria by using spread plate method. Plates were inoculated and incubated at $37{ }^{\circ} \mathrm{C}$ for 24 hours. All blue colored colonies were enumerated to calculate total coliform as cfu/g.

Enumeration of yeast and mold. Diluted samples were inoculated onto SDA medium supplemented with clorampheinicol $(40 \mathrm{mg} / \mathrm{L})$ by spread plate method as mentioned earlier. The plates were incubated at $25^{\circ} \mathrm{C}$ for $48-72$ hours. Visible colonies were counted and calculated as the total yeast and mold and recorded as cfu/g (15).

\section{RESULTS}

Bacterial loads in both packed and unpacked flour samples were tested in this study (Tables 1). Average counts of total heterotrophic bacteria were $1.19 \times 10^{7} \mathrm{cfu} / \mathrm{g}$ and $3.52 \times 10^{6} \mathrm{cfu} / \mathrm{g}$ in unpacked and packed flour samples, respectively. Mean concentrations of Staphylococcus aureus showed similar pattern having higher concentration in unpacked $\left(3.36 \times 10^{4} \mathrm{cfu} / \mathrm{g}\right)$ than packed $\left(1.12 \times 10^{3} \mathrm{cfu} / \mathrm{g}\right)$ flour samples. Average counts of total Enterobacteriaceae were $5.68 \times 10^{5} \mathrm{cfu} / \mathrm{g}$ and $1.24 \times 10^{5}$ $\mathrm{cfu} / \mathrm{g}$ in unpacked and packed flour samples, respectively. Mean of total coliform counts in unpacked flour $\left(4.0 \times 10^{5}\right.$ $\mathrm{cfu} / \mathrm{g})$ was higher than that of packed $\left(1.4 \times 10^{4} \mathrm{cfu} / \mathrm{g}\right)$ sample. Mean concentrations of total yeast and mold counts also showed similar pattern and demonstrated higher concentration $\left(2.12 \times 10^{5} \mathrm{cfu} / \mathrm{g}\right)$ in unpacked samples than packed $\left(4.08 \times 10^{5} \mathrm{cfu} / \mathrm{g}\right)$ flour samples.

Microbial load in both packed and unpacked bread samples tested in this study is shown in Table 2. The average counts of total heterotrophic bacteria were $2.01 \times 10^{6} \mathrm{cfu} / \mathrm{g}$ and $3.30 \times 10^{6} \mathrm{cfu} / \mathrm{g}$ in unpacked and packed bread samples, respectively. Averages counts of Staphylococcus aureus was found to be higher in unpacked bread $\left(1.93 \times 10^{4} \mathrm{cfu} / \mathrm{g}\right)$ than packed bread samples $\left(2.08 \times 10^{3} \mathrm{cfu} / \mathrm{g}\right)$. The average counts of total Enterobacteriaceae were $1.22 \times 10^{5} \mathrm{cfu} / \mathrm{g}$ and $4.84 \times 10^{4}$ $\mathrm{cfu} / \mathrm{g}$ in unpacked and packed bread samples, respectively. Mean concentrations of total coliform were $1.36 \times 10^{4} \mathrm{cfu} / \mathrm{g}$ and $1.86 \times 10^{4} \mathrm{cfu} / \mathrm{g}$ in unpacked and packed bread samples, respectively. The average total yeast and mold counts were $1.05 \times 10^{5} \mathrm{cfu} / \mathrm{g}$ and $1.01 \times 10^{5}$ $\mathrm{cfu} / \mathrm{g}$ in unpacked and packed bread samples, respectively.

Table 3 shows the background information of salespeople in both super and local markets engaged in selling flours and breads. All salespeople were found to

TABLE 1. Microbial load (cfu/g) in packed and unpacked flour samples

\begin{tabular}{|c|c|c|c|c|c|}
\hline Sample no. & THB (cfu/g) & SA (cfu/g) & TE $(c f u / g)$ & TC (cfu/g) & TYM (cfu/g) \\
\hline \multicolumn{6}{|c|}{ Unpacked (Local market) } \\
\hline 1 & $1.2 \times 10^{6}$ & $8.0 \times 10^{4}$ & $1.52 \times 10^{5}$ & 0 & 0 \\
\hline 2 & $4.2 \times 10^{7}$ & $4.0 \times 10^{3}$ & $1.84 \times 10^{5}$ & 0 & $6.0 \times 10^{3}$ \\
\hline 3 & $3.20 \times 10^{6}$ & $1.0 \times 10^{3}$ & $8.0 \times 10^{4}$ & 0 & $3.4 \times 10^{3}$ \\
\hline 6 & $5.20 \times 10^{4}$ & $3.1 \times 10^{3}$ & $2.80 \times 10^{4}$ & 0 & $5.5 \times 10^{4}$ \\
\hline 9 & $8.0 \times 10^{6}$ & $8.0 \times 10^{4}$ & $2.4 \times 10^{6}$ & $2.0 \times 10^{6}$ & $1.0 \times 10^{6}$ \\
\hline Average & $1.192 \times 10^{7}$ & $3.36 \times 10^{4}$ & $5.68 \times 10^{5}$ & $4.0 \times 10^{5}$ & $2.12 \times 10^{5}$ \\
\hline \multicolumn{6}{|c|}{ Packed (Super market) } \\
\hline 4 & $2.80 \times 10^{6}$ & 0 & $4.8 \times 10^{5}$ & 0 & $6.0 \times 10^{5}$ \\
\hline 5 & $3.20 \times 10^{6}$ & 0 & $8.0 \times 10^{4}$ & $1.60 \times 10^{4}$ & $5.20 \times 10^{5}$ \\
\hline 7 & $8.0 \times 10^{5}$ & $4.0 \times 10^{2}$ & $4.0 \times 10^{4}$ & $4.0 \times 10^{4}$ & $4.8 \times 10^{5}$ \\
\hline 8 & $8.8 \times 10^{5}$ & $1.2 \times 10^{3}$ & 0 & $1.2 \times 10^{4}$ & $4.4 \times 10^{5}$ \\
\hline 10 & $1.0 \times 10^{7}$ & $4.0 \times 10^{3}$ & $2.40 \times 10^{4}$ & $2.0 \times 10^{3}$ & 0 \\
\hline Average & $3.52 \times 10^{6}$ & $1.12 \times 10^{3}$ & $1.24 \times 10^{5}$ & $1.4 \times 10^{4}$ & $4.08 \times 10^{5}$ \\
\hline
\end{tabular}

$\mathrm{THB}=$ Total heterotrophic bacteria; $\mathrm{SA}=$ Staphylococcus aureus $; \mathrm{TE}=$ Total enterobacteriaceae; TC $=$ Total coliforms; TYM= Total yeast and mold 
TABLE 2. Microbial load (cfu/g) in packed and unpacked bread samples

\begin{tabular}{|c|c|c|c|c|c|}
\hline Sample no. & THB (cfu/g) & SA $($ cfu/g) & TE $(c f u / g)$ & TC $(\mathbf{c f u} / \mathrm{g})$ & TYM (cfu/g \\
\hline \multicolumn{6}{|c|}{ Unpacked (Local market) } \\
\hline 12 & $5.2 \times 10^{4}$ & $1.6 \times 10^{4}$ & $1.32 \times 10^{4}$ & 0 & 0 \\
\hline 13 & $1.16 \times 10^{4}$ & 0 & $8.0 \times 10^{3}$ & 0 & 0 \\
\hline 14 & $3.2 \times 10^{6}$ & $7.6 \times 10^{4}$ & $1.6 \times 10^{5}$ & $5.6 \times 10^{4}$ & $4.0 \times 10^{5}$ \\
\hline 15 & $2.4 \times 10^{6}$ & $4.0 \times 10^{3}$ & $3.2 \times 10^{4}$ & 0 & $6.4 \times 10^{4}$ \\
\hline 16 & $4.4 \times 10^{6}$ & $8.0 \times 10^{2}$ & $4.0 \times 10^{5}$ & $1.2 \times 10^{4}$ & $6.4 \times 10^{4}$ \\
\hline Average & $2.01 \times 10^{6}$ & $1.93 \times 10^{4}$ & $1.22 \times 10^{5}$ & $1.36 \times 10^{4}$ & $1.05 \times 10^{5}$ \\
\hline \multicolumn{6}{|c|}{ Packed (Super market) } \\
\hline 11 & $1.32 \times 10^{5}$ & $7.2 \times 10^{3}$ & $8.0 \times 10^{3}$ & 0 & 0 \\
\hline 17 & $4.8 \times 10^{6}$ & 0 & $1.2 \times 10^{4}$ & $1.2 \times 10^{3}$ & $4.8 \times 10^{4}$ \\
\hline 18 & $4.0 \times 10^{6}$ & 0 & $2.0 \times 10^{4}$ & $1.2 \times 10^{4}$ & $1.2 \times 10^{4}$ \\
\hline 19 & $3.6 \times 10^{6}$ & 0 & $2.0 \times 10^{3}$ & 0 & $7.2 \times 10^{3}$ \\
\hline 20 & $4.0 \times 10^{6}$ & $3.2 \times 10^{3}$ & $2.0 \times 10^{5}$ & $8.0 \times 10^{4}$ & $4.4 \times 10^{5}$ \\
\hline Average & $3.30 \times 10^{6}$ & $2.08 \times 10^{3}$ & $4.84 \times 10^{4}$ & $1.86 \times 10^{4}$ & $1.01 \times 10^{5}$ \\
\hline
\end{tabular}

$\mathrm{THB}=$ Total heterotrophic bacteria; $\mathrm{SA}=$ Staphylococcus aureus $; \mathrm{TE}=$ Total enterobacteriaceae $; \mathrm{TC}=$ Total coliforms; $\mathrm{TYM}=\mathrm{Total}$ yeast and mold

be male. Their educational qualifications were up to primary or secondary level. It was found that $40 \%$ salespeople had education up to primary level in super market, whereas $80 \%$ salespeople had education up to primary level in local market. Secondary level education amongst the salespeople in the supermarkets were higher $(60 \%)$ than those working in the local markets $(20 \%)$. Most of the sales people handling bread and flour demonstrated poor knowledge of food spoilage in local $(60 \%)$ and super (20-60\%) markets. However, 20-40\% of the workers did not have any previous knowledge of food spoilage. Although they have been working in food shops for a varying length of time, they did neither have any training on food contamination nor attended any such workshop. Consequently they did not appear to be aware of the importance of hand washing and using aprons while working in the food shops. Salespeople did not go through any routine medical checkup and $20 \%$ of them were found to have long fingernails. According to the disease history, salespeople in the local market $(80 \%)$ demonstrated higher rate of dysentery than those working in the supermarket (40-60\%).

\section{DISCUSSIONS}

Bread and bakery products are most widely consumed food all over the world. Even in Bangladesh bread and flour consumption is increasing due to health consciousness and to some extent for higher price of rice. They are good sources of nutrient and protein and provide high biological value in our diet. Variety of breads and other bakery products have gained popularity among consumers in the last decade and their sales have been increased notably.

This study has revealed presence of microorganisms in different types of bread and flour samples from different outlets. International microbiological standards recommended units of bacterial counts for dry and ready to eat foods are $10^{3}-10^{2} \mathrm{cfu} / \mathrm{g}$ for coliforms and $<10^{3} \mathrm{cfu} / \mathrm{g}$ for total heterotrophic bacteria (16). Total heterotrophic counts indicate general microbiological quality and hygienic status of any food sample. It was found that both packed $(n=5)$ and unpacked $(n=5)$ flour samples harbored heterotrophic bacteria above the international acceptable limit. Average concentrations of THB in unpacked flours were slightly higher $\left(1.192 \times 10^{7} \mathrm{cfu} / \mathrm{g}\right)$ than packed flours $\left(3.52 \times 10^{6} \mathrm{cfu} / \mathrm{g}\right)$. This may be due to the environmental contamination or erroneous handling of unpacked samples by the salespeople. However, no significant difference was found between the counts of THB of packed and unpacked bread samples ( $\mathrm{p}>0.05)$.

Environmental sources like, soil, water and air can act as sources of contamination of $S$. aureus. Lack of aseptic handling and personal hygiene can result in contamination of bread and flour with such bacteria. Their incidence is not always regarded as hazardous to consumers, as only coagulase positive Staphylococcus aureus can produce enterotoxin which may cause food borne diseases. However, to produce enterotoxin, it requires a high dose of Staphylococcus aureus $\left(10^{5}-10^{6} \mathrm{cfu} / \mathrm{ml}\right)$ in food (1719). In the present study, Staphylococcus aureus was observed in all 5 unpacked and 3 packed flour samples. Average count of $S$. aureus was found to be higher in unpacked $\left(3.36 \times 10^{4} \mathrm{cfu} / \mathrm{g}\right)$ than packed $\left(1.12 \times 10^{3} \mathrm{cfu} / \mathrm{g}\right)$ 
TABLE 3. Background information of salespeople in both super and local markets of flour samples

\begin{tabular}{|c|c|c|c|c|c|}
\hline \multirow[t]{2}{*}{ Criteria } & & \multicolumn{2}{|c|}{ Flour sample } & \multicolumn{2}{|c|}{ Bread sample } \\
\hline & & Super market & Local market & Super market & Local market \\
\hline \multicolumn{6}{|l|}{ Respondent information } \\
\hline \multirow[t]{2}{*}{ Gender } & Male & $5 / 5(100 \%)$ & $5 / 5(100 \%)$ & $5 / 5(100 \%)$ & $5 / 5(100 \%)$ \\
\hline & Female & 0 & 0 & 0 & 0 \\
\hline \multirow[t]{4}{*}{ Educational qualification } & Primary & $2 / 5(40 \%)$ & $4 / 5(80 \%)$ & $2 / 5(40 \%)$ & $4 / 5(80 \%)$ \\
\hline & Secondary & $3 / 5(60 \%)$ & $1 / 5(20 \%)$ & $3 / 5(60 \%)$ & $1 / 5(20 \%)$ \\
\hline & Higher secondary & 0 & 0 & 0 & 0 \\
\hline & Others & 0 & 0 & 0 & 0 \\
\hline \multirow[t]{4}{*}{ Working period (year) } & Less than 1 year & $1 / 5(20 \%)$ & $2 / 5(40 \%)$ & $2 / 5(40 \%)$ & $4 / 5(80 \%)$ \\
\hline & $1-5$ years & $4 / 5(80 \%)$ & $2 / 5(40) \%$ & $3 / 5(60 \%)$ & $1 / 5(20 \%)$ \\
\hline & $6-10$ years & 0 & $1 / 5(20 \%)$ & 0 & 0 \\
\hline & More than 10 years & 0 & $1 / 5(20 \%)$ & 0 & 0 \\
\hline \multirow[t]{5}{*}{ Knowledge on food spoilage } & Some & $1 / 5(20 \%)$ & $3 / 5(60 \%)$ & $3 / 5(60 \%)$ & $3 / 5(60 \%)$ \\
\hline & Poor & $3 / 5(60 \%)$ & 0 & $2 / 5(40 \%)$ & $1 / 5(20 \%)$ \\
\hline & Fair & 0 & 0 & 0 & \\
\hline & Good & 0 & 0 & 0 & \\
\hline & Very good & $1 / 5(20 \%)$ & $2 / 5(40 \%)$ & 0 & $1 / 5(20 \%)$ \\
\hline \multirow[t]{2}{*}{ Regular medical check up } & Yes & 0 & 0 & 0 & 0 \\
\hline & No & $5 / 5(100 \%)$ & $5 / 5(100 \%)$ & $5 / 5(100 \%)$ & $5 / 5(100 \%)$ \\
\hline \multirow{4}{*}{$\begin{array}{l}\text { Disease history in last } 1 \\
\text { year }\end{array}$} & Yes (Cholera/ Typhoid/ & & & & \\
\hline & Tuberculosis/ Skin infection & 0 & 0 & 0 & 0 \\
\hline & Dysentery & $3 / 5(60 \%)$ & $4 / 5(80 \%)$ & $2 / 5(40 \%)$ & $4 / 5(80 \%)$ \\
\hline & No & $2 / 5(40 \%)$ & $1 / 5(20 \%)$ & $3 / 5(60 \%)$ & $1 / 5(20 \%)$ \\
\hline \multirow[t]{2}{*}{ Attended seminar/ training } & Yes & 0 & 0 & 0 & 0 \\
\hline & No & $5 / 5(100 \%)$ & $5 / 5(100 \%)$ & $5 / 5(100 \%)$ & $5 / 5(100 \%)$ \\
\hline \multirow[t]{24}{*}{ Personal hygiene } & Hand washing practice & & & & \\
\hline & After go to toilet & $5 / 5(100 \%)$ & $3 / 5(60 \%)$ & $5 / 5(100 \%)$ & $3 / 5(60 \%)$ \\
\hline & Before eating & $5 / 5(100 \%)$ & $5 / 5(100 \%)$ & $5 / 5(100 \%)$ & $5 / 5(100 \%)$ \\
\hline & $\begin{array}{l}\text { After sneezing, touching hair and } \\
\text { clothes }\end{array}$ & 0 & 0 & 等 & 等 \\
\hline & $\begin{array}{l}\text { No } \\
\text { Hand washing with }\end{array}$ & 0 & $2 / 5(40 \%)$ & & $2 / 5(40 \%)$ \\
\hline & Only water & 0 & $2 / 5(40 \%)$ & 0 & $3 / 5(60 \%)$ \\
\hline & Soap & $3 / 5(60 \%)$ & $3 / 5(60 \%)$ & $5 / 5(100 \%)$ & $2 / 5(40 \%)$ \\
\hline & Antibacterial soap/savlon & 0 & 0 & 0 & 0 \\
\hline & Hand washing liquid & $2 / 5(40 \%)$ & 0 & 0 & 0 \\
\hline & Glove use & & & & \\
\hline & Yes & 0 & 0 & 0 & 0 \\
\hline & No & $5 / 5(100 \%)$ & $5 / 5(100 \%)$ & $5 / 5(100 \%)$ & $5 / 5(100 \%)$ \\
\hline & Hair restriction /tidy hair & & & & \\
\hline & Yes & $5 / 5(100 \%)$ & $5 / 5(100 \%)$ & $5 / 5(100 \%)$ & $5 / 5(100 \%)$ \\
\hline & No & 0 & 0 & 0 & 0 \\
\hline & Clean nails & & & & \\
\hline & No long finger nails & $5 / 5(100 \%)$ & $5 / 5(100 \%)$ & $5 / 5(100 \%)$ & $4 / 5(80 \%)$ \\
\hline & Long finger nails & 0 & 0 & 0 & $1 / 5(20 \%)$ \\
\hline & Wearing ring & & & & \\
\hline & Yes & 0 & $1 / 5(20 \%)$ & 0 & 0 \\
\hline & No & $5 / 5(100 \%)$ & $4 / 5(80 \%)$ & $5 / 5(100 \%)$ & $5 / 5(100 \%)$ \\
\hline & Apron/ uniform use & & & & \\
\hline & Yes & 0 & 0 & 0 & 0 \\
\hline & No & $5 / 5(100 \%)$ & $5 / 5(100 \%)$ & $5 / 5(100 \%)$ & $5 / 5(100 \%)$ \\
\hline
\end{tabular}

flour samples. Both types of flours showed bacterial loads lower than that required for effective enterotoxin production. For bread samples 4 unpacked and 2 packed samples were found to be contaminated with this organism. Average counts of $S$. aureus were $1.93 \times 10^{4}$ and $2.08 \times 10^{3} \mathrm{cfu} / \mathrm{g}$ in unpacked and packed bread samples, respectively. In another study Daniyan et al. (16) observed Staphylococcus aureus count in different stages of bread 
production which included mixing, milling and baking. After baking they found $2.20 \times 10^{4} \mathrm{cfu} / \mathrm{g}$ Staphylococcus aureus in bread samples (16).

Members of coliform group are indicator microorganisms which provide evidence about the hygiene standard maintained during production. Presence of coliforms in food sample suggests the presence of other enteric pathogenic bacteria samples contaminated and may pose risk to public health. In this study coliform was found to be present in 1 unpacked and 4 packed flour samples. The highest count of coliforms in unpacked sample was $2.0 \times 10^{6} \mathrm{cfu} / \mathrm{g}$ and while average count of packed sample were $1.4 \times 10^{4}$ $\mathrm{cfu} / \mathrm{g}$. In previous studies done in Pakistan and Australia showed presence of $10^{2}-10^{5} \mathrm{cfu} / \mathrm{g}$ coliform count in flour sample $(7,20)$. In this study $40 \%(n=2)$ unpacked and $60 \%(n=3)$ packed bread samples were found to be contaminated with coliforms. Average counts of coliforms were $1.36 \times 10^{4}$ and $1.86 \times 10^{4} \mathrm{cfu} / \mathrm{g}$ for packed and unpacked breads, respectively. Higher frequency and higher load of coliform bacteria present in packed and unpacked bread and flour indicate ineffective and inefficient packaging of product and contamination through the migration of substances from the packaging into the food products (21).

Members of family Enterobacteriaceae include a number of important pathogen, such as Salmonella, Yersinia enterocolitica pathogenic Escherichia coli (including E. coli O157:H7), Shigella spp. and Cronobacter spp. According to the NSW food authority, count of Enterobacteriaceae, $<10^{2} \mathrm{cfu} / \mathrm{g}$, is considered as good, $10^{2}$ to $<10^{4} \mathrm{cfu} / \mathrm{g}$ is considered acceptable and $\geq 10^{4} \mathrm{cfu} / \mathrm{g}$ is regarded as unsatisfactory in ready to eat food. In present study, $100 \% \quad(n=5)$ unpacked flour sample, Enterobacteriaceae counts were higher than the acceptable limit with an average of $5.68 \times 10^{5} \mathrm{cfu} / \mathrm{g}$. Most of the packed flour samples $(n=4,80 \%$ of $)$ was positive with an average count of $1.24 \times 10^{5} \mathrm{cfu} / \mathrm{g}$ of Enterobacteriaceae. For bread sample all packed and unpacked samples were positive for this group of organism. In unpacked bread sample average count was $1.22 \times 10^{5} \mathrm{cfu} / \mathrm{g}$ with $20 \% \quad(\mathrm{n}=1)$ sample within the acceptable range $8.0 \times 10^{3} \mathrm{cfu} / \mathrm{g}$. In packed bread sample $40 \%(n=2)$ fall within the acceptable range and showed average concentration of $4.84 \times 10^{4} \mathrm{cfu} / \mathrm{g}$.

The recommended limit for yeast and mold in flour is $10^{5} \mathrm{cfu} / \mathrm{g}$ (22). Molds can produce mycotoxin and higher concentration of these organisms can cause deterioration of food and food borne illness (23). Yeast and mold counts were found to lie below the recommended limit in all samples except one sample which showed $1.0 \times 10^{6}$ $\mathrm{cfu} / \mathrm{g}$ of yeast and mold in unpacked flour sample from local market.

Based on the questionnaire survey it was found that education level and hygiene status of bread and flour sellers were linked to the observed count of different microorganisms. In most of the cases the salespeople were not educated and trained properly which was reflected by their poor hygiene state. Only 60\% salespeople of local market showed hand washing practice after visiting toilet and $40-60 \%$ used just water for hand washing. Salespeople in the supermarket were more careful and found to use soap or hand washing liquid before handling foods than those in the local market. It was also found that $20 \%$ of the salespeople found to have unclean long fingernails and put on finger rings. According to the previous history of foodborne diseases, $40 \%-80 \%$ salespeople showed infection in the previous year which may further increase the chance of contamination of the bread and flour samples in the study year with coliform and other intestinal pathogens.

\section{CONCLUSION}

Bread and flour are known as safe food commodity due to their low water activity. But microbial isolation and enumeration in this study revealed prevalence of microorganisms including pathogens in higher counts than recommended limits for these food items. As flour and bread are most commonly consumed food products, their microbiological quality is important to consumer's health. A questionnaire survey among the salespeople indicated many underlying reasons of such poor microbiological standard, like disease history, hygiene practice and educational status. Therefore, stringent regulatory actions on the microbiological quality control on bread and flour together with the training of salespeople on food spoilage are necessary for the better management of public health condition in Bangladesh.

\section{ACKNOWLEDGEMENT}

Authors are thankful to the Department of Microbiology, Stamford University Bangladesh for all the technical help.

\section{REFERENCES}

Saranraj P, Geetha M. 2012. Microbial Spoilage of Bakery Products and Its Control by Preservatives. Int. J. Pharma. Biolog. Arch. 3 (1): 38-48.

Batool SA, Rauf N, Tahir SS, Kalsoom R. 2012. Microbial and physico-chemical contamination in the wheat flour of the twin cities of Pakistan. Int. J. Food Safety. 14: 75-82.

Pomeranz Y, Clifton EM. 1996. Food analysis: Theory and practice, $3^{\text {rd }}$ ed. CBS Publishers and Distributors, India.

Akobundu ENT. 2006. Bread making technology and ingredients for bread making. A paper presented at a training workshop on the use of cassava/wheat composite flour and non-bromated additives for making bread and other confectioneries. Held at Michael Okpara University of Agriculture, Umudike.

International Commission on Microbiological Specification of Food (ICMSF). 1998. Microorganisms in foods: Microbial ecology of food commodities. Blackie Academic and Professional, London.

Berghofer LK, Hocking AD, Miskelly D, Jansson E. 2003. Microbiology of wheat and flour milling in Australia. International Journal of Food Microbiology. 85: 137-149. 
7. Deibel KE, Swanson KMJ. 2001. Cereal and cereal products. In: Downes PF, Ito K (Eds), Microbiological examination of foods. American Public Health Association (APHA), Washington DC.

8. Cicognani G, Pedretti C, Cerrato A. 1975. Caratteristiche microbiologiche delle farine di frumento. Industrie Alimentari. 14: 60-64.

9. Ottogalli G, Galli A. 1979. Microbiological quality of flours: sour dough for bakery products and spaghetti; In: Jarvis B, Christian JHB, Michener $\mathrm{H}$ (Ed.), Proceedings of the International meeting on Food Microbiology and Technology. Tabiabo, Parma.

10. Spicher G. 1986. Merkpunktefür die Beurteilung der mikrobiologischhygienischen Qualitat von Weisenmehlen. Die Mühle \& Mischfuttertechnik. 33: 449 .

11. Eyles MJ, Moss R, Hocking AD. 1989. The microbiological status of Australian flour and the effects of milling procedures on the microflora of wheat and flour. Food Australia. 41: 704-708.

12. Richter KS, Dorneanu E, Eskridge KM, Rao CS. 1993. Microbiological quality of flours. Cereal Food World. 38: 367-369.

13. Cappuccino JG, Sherman N. 1996. A laboratory manual in general microbiology. $4^{\text {th }}$ ed. Benjamin Commius publication company, California.

14. ICMSF. 1978. Microorganisms in foods: Their significance and methods for enumeration. $2^{\text {th }}$ ed. Univ. of Toronto press. Toronto, Ontario, Canada.

15. Sharaf EM, Sabra SM. 2012. Microbiological loads for some types of cooked chicken meat products at Al-Taif Government, KSA. World Appl. Sci. J. 17 (5): 593-597.
16. Daniyan SY, Nwokwu OE. 2011. Enumeration of microorganisms associated with the different stages of bread production in Futmin bakery, Nigeria. Int. Res. J. Pharmacy. 2 (7): 88-91.

17. International Dairy Federation (IDF). 1994. Recommendations for the hygienic manufacture of milk and milk based products, appendix A. In: Spoilage and Pathogenic Bacteria in Milk Based Products. Int. Dairy Federation, Belgium

18. Jawetz E. 1987. Review on medicinal microbiology. Ed17, Norwalk: CT, Appleton \& Larpe.

19. Beys L, Hoest B. 1971. Investigation for staphylococci in foods, dietetic products and oral drugs. Rev. J. Food Protection. 25: 26-33.

20. Aydin A, Paulsen P, Smulders JM. 2009. The physico-chemical and microbiological properties of wheat flour in Thrace. Turkish J. Agri. Forestry. 33: $445-454$.

21. Oi-Wah Lau, Siu-Kay Wong. 2000. Contamination in food from packaging material. J. Chromatogra. A. 882 (1-2): 255-270.

22. World Food Program (WFP). 2012. Food quality control. Available at: www.wfp.org. Accessed 15 November, 2012

23. Bullerman LB. 1997. Fusaria and toxigenic molds other than Aspergilli and Penicillia, In: Doyle MP, Beuchat LR, Montville TJ (Ed.), Food microbiology. American Society for Microbiology Press, Washington DC. 